\title{
BNI Marketing Strategy for Credit Cards in Dealing Global Competition in State Bank Indonesia (Persero) Tbk Banda Aceh Branch Office
}

\author{
Erry Dianto ${ }^{1}$, Saibul Anwar ${ }^{2}$, Husnawati ${ }^{3}$, Zurnalis ${ }^{4}$ \\ ${ }^{1}$ Alumni Faculty of Economics, Muhammadiyah University of Aceh \\ ${ }^{2,3}$ Lecturer in Islamic Banking Study Program STAI Tapaktuan, South Aceh \\ ${ }^{4}$ Lecturer of STAI Tapaktuan, South Aceh \\ errydianto.bni@gmail.com
}

\begin{abstract}
This study aims to analyze the marketing strategy of BNI Credit Cards in the face of global competition at PT. Bank Negara Indonesia (Persero) Tbk Banda Aceh Branch Office. This study uses a qualitative approach with a descriptive type where the type of data used is secondary data sourced from various reports and documentation from PT. Bank Negara Indonesia (Persero) Tbk Banda Aceh Branch Office. The results of this study indicate that in marketing BNI Banda Aceh Branch credit cards a strategy that can be used is a marketing strategy that differentiates the market (Differentiated marketing), which is to determine the target market segmentation in accordance with the target types of credit card products that are in accordance with the segmentation. The Banda Aceh BNI branch also uses a concentrated marketing strategy such as the marketing of BNI-Unsyiah affinity Credit Cards which is focused on alumni of Syiah Kuala University throughout Indonesia. Besides that, another strategy used by the Banda Aceh BNI branch in marketing BNI Credit Cards is by issuing pre aproval credit cards, where certain customers in accordance with applicable regulations are directly proposed to issue credit cards on behalf of these customers, if the customer agrees for card issuance, the card can be activated immediately. Furthermore, BNI provides the convenience of non-cash transactions through the YAP (Your All Payment) application as a payment tool for (cashless) and without showing the debit card or credit card (Cardless) through a smartphone. This YAP application is an advantage owned by BNI and the first in Indonesia.
\end{abstract}

Keywords

marketing strategy; BNI Credit Card

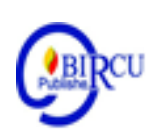

\section{Introduction}

In an increasingly advanced era like now it's not just money that is used as a means of payment but there are also ATM cards or debit cards and cards that are a symbol of lifestyle, namely Credit Cards. But many people who do not know what a credit card is. Most of them say that credit cards are only for rich people, so if someone is offered a credit card by the card issuer or the bank that issued the credit card, they will certainly avoid or reject the offer with various reasons, such as fear of debt, add a lot of costs, life becomes more wasteful, and others. Today the Indonesian people have a great interest in the existence of credit cards. Trends in the use of credit cards in Indonesian society continue to experience a significant increase from year to year (starting from 2013 to 2017), as can be seen from Table I-1 Based on Bank Indonesia data, it was stated that up to December 2017 last the number of credit card 
holders in Indonesia reaches more than 17 million based on the number of cards, although the number of cards has decreased compared to 2016 due to policies in several Issuing Banks to remove card ownership from users who are no longer active or unable to fulfill obligations according to the time that has passed determined. Card number, transaction volume and transaction value as shown in the table below:

Table 1. Credit Card Business Trends Based on Card Number, Transaction Volume and Transaction Value in Indonesia

\begin{tabular}{|c|c|c|c|}
\hline Year & $\begin{array}{c}\text { ard } \\
\text { Amount } \\
\text { (piece) }\end{array}$ & $\begin{array}{c}\text { Transaction } \\
\text { Volume } \\
\text { (Transaction } \\
\text { Amount) }\end{array}$ & $\begin{array}{c}\text { Transaction } \\
\text { Value } \\
\text { (in millions) }\end{array}$ \\
\hline 2013 & 15.091 .684 & 239.098 .579 & 223.369 .577 \\
\hline 2014 & 16.043 .347 & 138.064 .605 & 255.057 .458 \\
\hline 2015 & 16.863 .847 & 154.001 .921 & 273.141 .967 \\
\hline 2016 & 17.406 .327 & 305.052 .297 & 281.020 .518 \\
\hline 2017 & 7.244 .127 & 327.490 .317 & 275.270 .000 \\
\hline
\end{tabular}

Source : bi.go.id, 2018

The growth rate of the credit card business, which has significantly increased from year to year, can show that people's purchasing power is also increasing. This has become a positive indicator for credit card business players that credit card growth will be more prospective in the future.

PT Bank Negara Indonesia (Persero) Tbk or commonly known by the public as Bank BNI 46 is one of 23 banks in Indonesia that issues Credit Cards in which the Credit Card business in BNI is still the Market Leader with a total card ownership of 1.8 million with transaction volume around Rp. 35 trillion at the end of 2017, while for 2018 BNI is targeting the volume and value of Credit Card transactions to grow 2 digits or at least the same as the market.

The above is a challenge for BNI in the future so it is necessary to prepare an appropriate marketing strategy to introduce and build awareness among customers and the public about the existence of BNI Credit Card products. Moreover, Bank Indonesia has launched the National Non-Cash Movement (GNNT) since 2014 which aims to bring Indonesia into the era of people without money or Cashless Society. This is also evident by the growing development of cashless payment instruments that use Android-based applications and other applications such as server-based electronic money, Tokopedia's Cash Shop, Shopee's Shopeepay, Grab's Grappay and Ust's Paytrend. Yusuf Mansur and other Android-based applications that are developing, namely OVO.

The Branch Office BNI Banda Aceh itself continues to boost its credit card marketing where it can be seen from the development of credit card marketing as of the last 4 years, can be seen in the table below: 
Table 2. Development of Credit Card Marketing PT Bank Negara Indonesia (Persero), Tbk Banda Aceh Branch Office 2014-2017

\begin{tabular}{|c|c|c|c|c|c|}
\hline Year & $\begin{array}{c}\text { Targ } \\
\text { et }\end{array}$ & $\begin{array}{c}\text { Applic } \\
\text { ation } \\
\text { Entry }\end{array}$ & $\begin{array}{c}\text { Unappro } \\
\text { ved Card }\end{array}$ & $\begin{array}{c}\text { Approve } \\
\text { d card }\end{array}$ & $\begin{array}{c}\text { \%chievem } \\
\text { ent of } \\
\text { targets }\end{array}$ \\
\hline 2014 & 200 & 392 & 222 & 171 & $86 \%$ \\
\hline 2015 & 371 & 522 & 363 & 153 & $41 \%$ \\
\hline 2016 & 348 & 532 & 333 & 162 & $47 \%$ \\
\hline 2017 & 350 & 458 & 309 & 149 & $43 \%$ \\
\hline
\end{tabular}

Source : CNM Medan, 2018

From the table above, in the implementation of BNI Credit Card marketing shows that there was a decline in credit card acquisition compared to 2014 by $86 \%$ to $41 \%$ in 2015 and $47 \%$ in 2016. In terms of the number of approved cards there was also a decrease from 2014 by 171 cards dropped to 153 cards in 2015, 162 cards in 2016 and 149 Cards in 2017.

Based on the description above, it can be seen that there is a decline in BNI Credit Card acquisition performance due to the large number of unapproved card applications compared to the number of approved cards, so this research was conducted at PT. Bank Negara Indonesia Banda Aceh Branch Office to analyze the problem of BNI Credit Card marketing strategies in facing global competition at PT. Bank Negara Indonesia Banda Aceh Branch Office using descriptive analysis to determine the extent to which the marketing strategies used have been effective in supporting the achievement of credit card business performance.

\section{Review of Literature}

\subsection{Understanding of Marketing}

The definition of marketing according to the American Marketing Association (AMA) as quoted by Kasali (2010: 53) is: Marketing is a process of planning and execution, starting from the conception stage, pricing, promotion, to the distribution of goods, ideas and services, to make exchanges that satisfy the individual and his institutions.

\subsection{Understanding of Marketing Strategy}

Chandra (2008: 93) that: "Marketing strategy is a plan that outlines the company's expectations of the impact of various marketing activities or programs on the demand for products or product lines in certain target markets". According to Andrews in Alma's book (2009: 199) that: "Marketing strategy is a pattern of decisions in companies that determine and express goals, intentions or goals that produce the main policy and plan for the achievement of objectives and detail the range of business that will be pursued by the company."

Marketing communication can shape brand equity and improve promotional performance (Bogan 2014). The development of marketing communication that changes very rapidly through advertising is not the only or the most important thing in establishing brand equity and driving sales, but can also be a mean which increases equity and drive sales through a mix of marketing communication. Moreover, expanding this communication can also make the product or tourism object reach a wider market. Marketing communication mix is done to encourage the effectiveness and efficiency of marketing communication which 
consists of eight main communication models, including advertising, sales promotion, events and experience, public relations, direct marketing, interactive marketing, word of mouth marketing, and sales personnel (Philip Kotler in amin, 2019).

Therefore, the determination of marketing strategies must be based on an environmental and internal analysis of the company through an analysis of the company's strengths and weaknesses, as well as an analysis of the opportunities and threats faced by the company from its environment. The process of selecting a marketing strategy requires careful Consideration of a number of types of information:

1. Product goals or objectives

Product objectives should be used as guidelines in determining the basic types of strategies needed. For example, if the main purpose of a product is to increase sales volume or market share growth, then usually the main alternative considered is a selective demand strategy that focuses on grabbing customers from competitors or expanding the market being served.

2. Market opportunities

The characteristics and magnitude of market opportunities must be clearly established based on market analysis and market measurements. Market analysis provides information about who bought the form of the product (and who did not buy it), various situations of product clothing (and also situations that did not use the product).

3. Market success

Marketing managers must understand the type of competitive advantage and the level of marketing expenditure needed to achieve market success. Through competition analysis, companies can understand who their competitors are, what level of intensity of competition there is, and what advantages must be developed in order to compete selectively against direct brand competitors or indirect product class competitors.

Environmental factors analyzed in the formulation of marketing strategies are the state of the market or competition, technological development, socio-cultural and political conditions. The company's internal factors analyzed in the formulation of marketing strategies are factors related to the implementation of company functions, which include finance / expenditure, marketing, production and organization and human resources.

\subsection{Types of Marketing Strategies}

Assauri (2008: 163) that in general marketing strategies, three types of marketing strategies can be distinguished from companies, namely:

1. Marketing strategies that do not discriminate the market (Undifferentiated marketing).

With this strategy, the company considers the market as a whole, so the company only pays attention to the needs of consumers in general. Therefore the company only produces and markets one type of product and tries to attract all buyers and prospective buyers with a marketing plan.

2. Marketing strategies that differentiate the market (Differentiated marketing).

With this strategy, companies only serve the needs of certain groups of consumers with certain types of products. So companies or manufacturers produce and market different products for each market segment. In other words, the company or manufacturer offers a variety of products and product mix, which are tailored to the needs and desires of different groups of consumers or buyers, with a separate marketing program that is expected to achieve the highest level of sales in each of these market segments.

3. Concentrated marketing strategy.

With this strategy, the company specializes in marketing its products in several market segments, taking into account the limitations of the company's resources. In this case, the 
producer company chooses a certain market segment and offers products that fit the needs and desires of the existing consumer groups in that market segment, which is certainly more specific. This marketing strategy prioritizes all marketing efforts in one or several specific market segments. So the company focuses all activities will provide the greatest benefits.

\subsection{Service Marketing Mix}

In marketing services known marketing mix strategy (marketing mix). According to Tjiptono (2011: 39) The service marketing mix is a set of tools that marketers can use to shape the characteristics of services offered to customers which include products, prices, promotions, places, people, physical evidence, customer processes and services.

\subsection{Types of Service Marketing Mix}
1. Product
2. Price
3. Promotion
4. Place
5. People
6. Process
7. Physical Evidence

\subsection{Activities in the Marketing Mix}

In the competitive world of credit card business that is increasingly competitive today there are various kinds of marketing activities in order to achieve the targets set. These marketing activities include Advertising, Sales Marketing, Publicity and Public Relations, Direct Marketing, Marketing Financing

\subsection{Selection of Marketing Strategies}

Based on the study of literature on the factors that influence marketing strategies, interviews with representatives of company management and combined with the results of observations conducted by researchers, it can be seen the factors that influence the preparation of marketing strategies namely Marketing Budget, Human Resources, Market Characteristics, characteristics product.

\subsection{Marketing Strategy Approach}

The marketing mix is strongly influenced by the selection of marketing strategies adopted by the company. Two strategic approaches that can be applied are push strategy and pull strategy. The push strategy approach is aimed at those involved in distribution channels (such as agents, retailers, and wholesellers). This strategy is useful to include producers who use salespeople and trade marketing to persuade intermediaries to take, market and sell products to end users. Whereas the pull strategy approach includes producers using advertising and consumer marketing to encourage end users to request the product from intermediaries and thus encourage intermediaries to order the product from producers. 


\subsection{Bank Defenition}

The bank is simply defined as a financial institution whose business activities are collecting funds from the public and channeling these funds back to the community and providing other bank services. According to banking principal Law No.10 of 1998 quoted by Idroes (2008: 15) which regulates the main banking regulations in Indonesia define as follows:

"Banks are business entities that collect funds from the public in the form of deposits and distribute them to the public in the form of credit and or other forms in order to improve the lives of many people."

\subsection{Credit card}

Beginning in the early 1900s in the United States, several fueling companies (gas stations) and department stores have actually introduced a kind of shopping card that can be used by their consumers. But this card was issued by the company and its function was limited to being a member card, as we often encountered, such as the Centro Club Card and so on. This system is known as "Charge-It" and was introduced by a banker named John Biggins from Flatbush National Bank of Brooklyn which aims to make it easier for consumers (bank customers) to transact with shops or merchants who are also customers at the bank.

The next development is called the Diners Club Card. It started in 1949 accidentally when a businessman named Frank McNamara forgot his wallet after a dinner at a well-known restaurant. From here Frank McNamara debuted to find a cash or wallet replacement solution that might also often be experienced by restaurant consumers the other. In 1950, Frank McNamara and his colleague, Ralph Schneider, returned to the restaurant using a unique payment card. This is the forerunner of the credit cards that we know today. It all started with Diners Club, which at that time was a type of "charge card". Charge Card, which means a delay card. It was only in 1951 when many Americans began to use it that plastic was used as a raw material in its current form. In 1958, American Express issued a credit card called AMEX. Then followed by Bank of America issued a credit card, namely VISA. Furthermore, in the 1970s, the American government issued policy regulations regarding the rules and use of credit cards. Since then, credit card companies have expanded rapidly throughout the world.

\subsection{Development of Credit Cards in Indonesia}

The development of the credit card business in Indonesia is now increasingly lively. This can be seen from the continuously increasing types of credit cards issued, the increasing number of customers, and the increasing number of outstanding credit cards and the value of transactions in the last six years (2005-2010). If in 2005 the number of credit cards in circulation in Indonesia was recorded at 8.34 million cards with a transaction value of $\mathrm{Rp}$. 51.67 trillion, in 2009 the number of cards in circulation had reached 13.41 million cards with a transaction value of Rp. 273.14 trillion. Until the end of 2017, the number of credit cards in circulation in Indonesia has reached 17.22 million cards with a transaction value of $\mathrm{Rp}$ 275.27 trillion. This is because credit cards are now increasingly popular as a cash replacement tool and have even become part of the lifestyle of modern society in Indonesia. Besides being triggered by the development of people's lifestyles in big cities, the growth of the credit card business is also supported by a variety of interesting programs offered by issuing companies, following the increasingly varied tastes and needs of customers. 


\subsection{Definition of Global Competition}

Basically, global competition does not yet have a well-established meaning (standard definition). It means that global competition still has various meanings or it still depends on the point of view of people in seeing it. Global competition can be seen from the economic, social, cultural aspects as well as from other aspects that cause interactions and competition between people in the world.

In general, global competition is defined as a form of world-level competition in which every country has the right to compete without being limited by territory. Global competition is also often interpreted as a form of agreement between countries in the world to be able to actualize itself by removing the geographical, economic and cultural boundaries of society.

Global competition in this study is defined as competition in marketing credit card products with economic cooperation between countries carried out by the Indonesian government with countries in Southeast Asia, namely ASEAN, where one of the economic cooperation is the AFTA or Asean Free Trade Area is a form of regional cooperation ASEAN countries to create a free trade area that only applies to ASEAN countries in order to increase economic competitiveness for the sake of continued skyrocketing economic growth.

\section{Research Method}

\subsection{Location and Research Object}

This research uses a qualitative approach with a descriptive type where the type of data used is secondary data sourced from various reports and documentation of PT. Bank Negara Indonesia (Persero) Tbk Banda Aceh Branch Office which is made periodically which is closely related to this research both data sourced from the Medan Card and Merchant and from the Card Business Division in Jakarta. This research was conducted from September 1, 2017 to December 31, 2017 with the unit of analysis is PT. Bank Negara Indonesia (Persero) Tbk Banda Aceh Branch Office, while the research observation unit is the BNI Credit Card Product.

\subsection{Technique of Collection Data}

To obtain information and data needed in this writing, the authors use data collection techniques as follows:

1. Documentation, namely data collection by studying company reports and documentation concerning the marketing activities of Credit Card products at PT. Bank Negara Indonesia (Persero) Tbk Banda Aceh Branch Office.

2. Interview is a data collection technique carried out by holding direct interviews with company leaders and a number of employees who have a direct relationship with the problem that the authors put forward.

\subsection{Technique of Analysis Data}

The analysis technique used is descriptive analysis which is a technique used by analyzing and describing to describe the state of the object under study which is the center of attention in research (Nazir, 2007: 16). Descriptive analysis techniques are used to help identify and expose the elements that are the focus of research. Sudjana and Ibrahim (2007: 64) suggest that descriptive methods suggest descriptive analysis is used to describe a phenomenon, event, event at the time the research takes place. In other words, descriptive analysis method is used to describe and then describe the state of the object under study with the things that are the center of attention. In this research, descriptive analysis is used to 
explain the marketing strategy of PT Bank Negara Indonesia (Persero) Tbk, Banda Aceh Branch Office in marketing Credit Card products in the face of global competition.

\section{Discussion}

\subsection{Analysis Development of BNI Credit Card Holder Customers}

To support the marketing activities of BNI Credit Card products, one of the visions to be achieved is to increase the number of BNI Credit Card holders. An increase in the number of customers will affect the marketing performance of BNI Credit Cards and will increase promos held in Banda Aceh.

BNI Banda Aceh Branch, is one of the companies engaged in banking services. In carrying out its activities as a company engaged in banking, it is necessary to analyze the development of BNI Credit Card marketing performance. This is intended to evaluate the customer's development

Based on the observations made by the author, it appears that the use of the above marketing channels was quite efficient and good, where in marketing BNI Credit Cards in addition to using existing marketing personnel also involved all BNI Banda Aceh Branch employees, each of whom played a role in finding prospective customers with goals as follows:

1. BNI Bank loyal customers, both individuals and companies that already have savings products, savings, current accounts and deposits that are eligible to be offered BNI Credit Card products.

2. Agency or institution that has cooperated with BNI Banda Aceh Branch to channel employee salary payment through BNI Payroll

3. Individuals and Non-Customer companies, both those who trade at counter tellers and at Customer Service (walk in customers)

\subsection{BNI Credit Card Marketing Strategies}

\section{Current Credit Card Marketing Mix Activity}

In the increasingly competitive world of credit card business, Bank BNI has carried out various marketing activities in order to achieve the targets set. One of the marketing activities carried out by Bank BNI is advertising. Advertising is an important tool in relation to Bank BNI's strategy to market BNI Credit Card products. The following is a series of advertising activities carried out by Bank BNI for marketing BNI Credit Cards, including:

- Print Ad as an effort to use the press and print media for its credit card advertising activities, Bank BNI utilizes several national and local newspapers and magazines as a place to place advertisements (print ad). So far the BNI Credit Card print ad has been placed in Garuda Indonesia's premium magazine, Colors. In addition to general / commercial print media, print ad is also placed in the company's internal magazines. The print ad in this magazine is very beneficial because it is in national and local print media (at certain events) in the back of the front page of the magazine and in full page size.

- TVC (Television Commercial) Efforts to introduce and develop public awareness of BNI Credit Cards are also taken by Bank BNI by using TVC at certain events. In addition, BNI Credit Card advertisements are also often inserted at every BNI Bank on air event on television. For example, during the drawing of BNI Taplus Fortune, a soccer match where BNI sponsored one of the League 1 clubs, Bhayangkara FC. Aside from TVC on television, Bank BNI also advertises BNI Credit Cards through ad lips on the radio. For 
local radios BNI Banda Aceh Branch has collaborated with Radio Serambi FM and Radio Three FM, usually done at certain events and at launch new product.

- The BNI Credit Card brochure is focused on highlighting the features of BNI Credit Card features such as cheap interest, personal accident insurance and free annual fees. For specifications, BNI Credit Card brochures measuring $30 \times 21 \mathrm{~cm}$ with 180 gram mat paper material. Besides distributing brochures to all Branch Offices, they are also distributed during direct selling, gathering and exhibition activities. Banners are placed one piece each in each Branch Office with targets, namely customers and non-customers of each Branch Office. Banners are expected to be the initial media to build customer awareness from each branch office on BNI Credit Cards.

- Paper Bags are distributed both to BNI Credit Card holders and prospective card holders at BNI Credit Card marketing events such as gathering and exhibition activities.

BNI Credit Card promos currently underway include:

a. Giordano (All Outlet), 20\% discount for regular products until May 12, 2019.

b. Nike (All Outlet), 10\% discount for regular products with a minimum transaction of Rp. 1 million, Installment 0\% 3 Months (minimum transaction of IDR 2 million) and 6 months (minimum transaction of IDR. 4 million, valid until May 12, 2019.

c. Tiberland (Center Point), $10 \%$ discount for regular products with a minimum transaction of Rp. 500 thousand, Installment 0\% 3 Months (minimum transaction of Rp. 4 million) and 6 months (minimum transaction of Rp. 6 million) valid until 12 May 2019.

In addition to the above-mentioned promos, there are still many promos at star hotels, economical shopping promos at certain supermarkets and splashy promos both local and national.

\subsection{Selection of Marketing Strategies}

STP (Segmentation, Targeting and Positioning)

A clear and effective STP is one of the success factors of the marketing strategy implemented by BNI's Banda Aceh Branch in marketing credit cards. BNI Banda Aceh in marketing credit cards has segmented the market according to the type of credit card owned and has determined the target market according to the type of credit card, among others, as follows:

- For regular types of credit cards namely BNI Visa / MasterCard Silver and Gold, the targets are the Civil Servants who are in the environment of the Government of Aceh, housewives who have deposits in BNI with certain fund holders, Teachers / Public Lecturers.

- For the type of affinity cards that have collaborated with BNI, namely the BNI Unsyiah affinity card, the target market is Syiah Kuala University alumni who wish to contribute to the campus using the BNI Unsyiah Credit Card will be set aside for the benefit of the campus in accordance with applicable regulations agreed between BNI and Syiah Kuala University, Banda Aceh.

- For premium card types, the main target is young entrepreneurs who are energetic and want to look more brilliant using BNI credit cards. Besides that, it is also intended for civil servants or private parties who are eligible to be given a premium card.

- For the type of BNI Credit Card, the Corporate Card is a BNI credit card given to employees with a certain level or position of a company that can be used as a means of payment or transactions related to company activities, currently there are several government and private agencies that have collaborated with BNI to use the BNI 
Corporate Card for expenses such as airline tickets in cooperation with Garuda Indonesia using the BNI Corporate Card.

After determining the segmentation and target market as mentioned above, the Positioning that Bank BNI is trying to build for BNI Credit Cards is a favorite credit card where there are many choices of cards according to segmentation.

\subsection{Competition}

There are several banks that become BNI's main competitors in marketing credit cards in Banda Aceh, namely BCA, Mandiri, BRI and CIMB Niaga. The level of competition in marketing credit cards is very fierce in Banda Aceh where many competing banks currently provide programs and promos at merchants to pamper existing credit card holders and to attract public interest in using credit cards. This looks like a promo done at Ace Hardware Suzuya Mall where the promo applies to members and users of BCA, Mandiri, CIMB Niaga, BRI and BNI bank credit cards not wanting to miss participating in the promo. Not only at Ace Hardware, the joint promo was also held at Informa Banda Aceh. So that the competition of the five banks is very visible in marketing credit cards.

\subsection{Implications of Research Results}

After doing all the research on credit card marketing strategies at PT Bank Negara Indonesia (Persero) Tbk, Banda Aceh Branch Office, the authors obtain the implications from the company for the development of BNI credit card marketing. These implications cover a variety of ways undertaken or taken by BNI Banda Aceh Branch, including:

a) In marketing credit cards BNI Banda Aceh Branch uses a marketing strategy that differentiates the market (Differentiated marketing) where in marketing credit cards, BNI Banda Aceh Branch determines the market segmentation to be targeted according to the target type of credit card product that is in accordance with the segmentation. In addition to the above strategies BNI Banda Aceh Branch in marketing credit cards also uses concentrated marketing strategies such as marketing of BNI-Unsyiah affinity Credit Cards focused on alumni of Shia Kuala universities throughout Indonesia.

b)Providing convenience facilities for customers using BNI credit cards by issuing pre aproval credit cards, where certain customers in accordance with applicable regulations are immediately proposed to issue credit cards on behalf of these customers and subsequently after the cards are sent to BNI Banda Aceh Branch, marketing staff will contact the customer, if the customer agrees to the card issuance directly, the card can be activated. The pre aproval credit card issuance can be done for BNI debtors and agencies that have collaborated with BNI in using payroll services to pay salaries at BNI.

c) Providing the latest ease of service for credit card users, which now no longer needs to carry a physical credit card with BNI's flagship product, the YAP (Your All Payment) application as a payment tool for non-cash transactions (cashless) and without showing the debit card or credit card ( Cardless). YAP application is a payment solution today that is done by scanning a QR code through a smartphone. This application can be downloaded at Playstore and Appstore.

d)Conducting BNI Credit Card selling days in accordance with the market segmentation of each credit card continuously not only limited to selling days held nationally.

e) Increase promos by using BNI credit cards at merchants in the Aceh region, especially in Banda Aceh, considering that competitor banks are very active in conducting credit card promos. 
The above is a strategy used by the Banda Aceh BNI Branch to exceed the credit card sales target set by the Medan Medan BNI. Besides that, the bank also continues to improve in convincing the public that they are not mistaken in choosing the same bank product in meeting their needs by using a credit card.

\section{Conclusion}

Based on the results of the research and discussion described in the previous chapter, the conclusions from this study can be drawn, namely:

1. There are six factors making up the BNI Credit Card marketing strategy which consists of marketing budget, human resources, market characteristics, product characteristics, STP (segmentation, targeting and positioning) and competition. The STP factor is a top priority because it is used as a direction for the marketing strategy that will be implemented, so that the expansion of BNI Credit Cards can run quickly and on target.

2. BNI is one of the banks that issue the most credit cards according to segmentation, making BNI the favorite bank as an option for applying for credit cards.

3. Currently, BNI has cooperated with Syiah Kuala University to issue an affinity card, BNI - Unsyiah Credit Card, which is intended for all Syiah Kuala University academicians and alumni.

4. For marketing BNI Credit Cards at this time BNI Banda Aceh has not used print and radio media so that in advertising BNI Credit Card products still use brochures.

\subsection{Suggestion}

Based on the results of the research and discussion described in the previous chapter, the suggestions of this study are:

1. The implementation of BNI Credit Card marketing activities needs to be done intensively and continuously by utilizing all BNI employees, it is not enough to just be a crosseling product when customers transact at tellers and Customer Service Officers but rather it is done by all BNI employees because All Employees are Marketers.

2. The issuance of BNI Credit Cards using the Pre Approval system is very effective where the proposed customers are potential customers or debtors who do not need to wait for credit card approval.

3. The use of local print and radio media can be used as a means to advertise BNI Credit Cards where Print Media such as Newspapers can reach all levels of society, likewise radio can be chosen radio that has a specific listener segment that fits the BNI Credit Card segmentation so that it is right on target .

4. When participating in certain events both conducted by BNI itself and other parties, BNI Credit Card products can be used as one of the mainstay products to be marketed considering BNI provides many card options.

5. For further research it is recommended to use a more comprehensive method to analyze credit card marketing strategies. 


\section{References}

Alma, B. (2007), Manajemen Pemasaran dan Pemasaran Jasa: Edisi Revisi, Bandung: Penerbit Alfabeta.

Amin, M. (2019). Marketing Communication Strategy To Improve Tourism Potential.

Budapest International Research and Critics Institute (BIRCI-Journal). P. 160-166.

Angipora, (2008), Dasar-dasar Pemasaran. Edisi Kedua, Jakarta: PT RajaGrafindo Persada.

Durianto et al. (2008), Invasi Pasar dengan Iklan yang Efektif : Strategi, Program dan

Teknik Pengukuran, Jakarta : PT Gramedia Pustaka Utama.

Djawhari, (2013), Report Pengguna Kartu Kredit, Jakarta : Bank Indonesia.

Bank Indonesia, (2017), Sistem pembayaran instrumen non tunai kartu https://www.bi.go.id/id/sistem-pembayaran/instrumen-

nontunai/kartu/Contents/Default.aspx diakses tanggal 05 Mei 2017.

Kasmir, (2008), Pemasaran Bank, Jakarta : Prenada Media

(2009), Manajemen Perbankan. Jakarta : PT RajaGrafindo Persada.

Kotler, (2004), Manajemen Pemasaran : Analisis, Perencanaan, Implementasi dan Pengendalian. Jilid Dua. Edisi Kesembilan, Jakarta: PT. Prenhallindo.

Wirdaningsih, W., \& Mardhatillah, M. (2016). Penerapan Media Audio-Visual Terhadap Keaktifan Pada Materi Hubungan Antara Sumber Daya Alam Dengan Lingkungan Siswa Kelas IV SD Negeri Pasi Teungoh Kecamatan Kaway XVI. Bina Gogik: Jurnal Ilmiah Pendidikan Guru Sekolah Dasar, 3(2).

Kotler dan Gary Armstrong, (2007), Prinsip-Prinsip Pemasaran. Jilid Satu. Edisi Kedelapan, Jakarta : Penerbit Erlangga.

Lovelock C.H. dan L.K. Wright, (2005). Manajemen Pemasaran Jasa, Jakarta : PT Indeks Kelompok Gramedia.

Shimp, A.T, (2003), Periklanan dan Promosi : Komunikasi Pemasaran Terpadu, Jakarta: Erlangga.

Tjiptono, (2006), Manajemen Jasa.Edisi Ketiga, Yogyakarta: Penerbit ANDI.

Triandaru S. dan Totok B, (2006), Bank dan Lembaga Keuangan Lain. Edisi 2, Jakarta: Penerbit Salemba Empat.

Yazid, (2005), Pemasaran Jasa Konsep dan Implementasi, Yogyakarta: Penerbit Ekonisia Kampus Fakultas Ekonomi UII.

Mahrani, Disa (2013), Strategi Penjualan Kartu Kredit BCA pada Bank BCA Cabang Banda Aceh, Skripsi Fakultas Ekonomi Universitas Muhammadiyah Aceh, Banda Aceh.

Mardhiah, Cut Ainun Siti (2016), Perbandingan Sistem Kartu Kredit Syariah dan Kartu Kredit Konvensional pada Bank BNI Syariah dan BNI Konvensional Cabang Palembang, Skripsi UIN Raden Fatah Palembang.

Adiguna, Kadek Hendra (2017), Pelaksanaan Prinsip Mengenal Nasabah (Karakter) dalam transaksi dengan Kartu Kredit, Skripsi Universitas Warmadewa, Denpasar.

Malelak, Mariana Ing (2016), Pengaruh Faktor Demografi terhadap perilaku pengguna Kartu Kredit, Jurnal Inovasi dan Bisnis, Volume 4, No. 2 halaman 173-188.

Mardhatillah, M., Verawati, V., Evianti, E., \& Pramuniati, I. (2019). BAHAN AJAR INTERAKTIF BERBASIS KEARIFAN LOKAL MELALUI PENDEKATAN 
SAINTIFIK PADA PEMBELAJARAN BAHASA INGGRIS. Genta Mulia: Jurnal Ilmiah Pendidikan, 10(1).

Nisaputra, Rezkiana, (2018), Nilai transaksi kartu kredit di 2017 menurun. http://infobanknews.com/nilai-transaksi-kartu-kredit-di-2017-menurun// diakses tanggal 24 Januar 